\section{Ban All Production and Export of Chrysotile Asbestos}

The disturbing image on the cover of this issue of the Canadian Journal of Public Health shows a child in Indonesia sifting barehanded through a dump littered with asbestos. Two adults with bags - one with the logo of Lab Chrysotile, an asbestos mine in Quebec - are also looking for pieces of chrysotile-containing cement widely used in construction in that country. The pieces of cement can be manipulated and cut by workers wearing no more protection than the villagers in the image, resulting in the release of asbestos fibres and exposure of workers and families alike.

I recently commented on Canada's shameful practice of chrysotile export to low- and middle-income countries. New developments require a vigorous response from the public health community. An Indian group of investors has offered to save from bankruptcy the Quebec Jeffrey Mine, one of the last producers of chrysotile in Canada. Combined with a loan guarantee by the Quebec government, this may allow the continued export of chrysotile for the next 25 years. This must not come to pass.

Both the Canadian and Quebec governments have been supporting the asbestos industry for decades. The image from Indonesia illustrates why the assertion from the industry that chrysotile can be used safely is a sophism. Countries to which it is exported offer weak or no worker protection. In addition, exposure of the general population, as illustrated here, is likely quite extensive, impossible to document and to prevent and will likely persist for decades. While governments in Canada spend millions to remove asbestos from public buildings, the export of Canadian chrysotile is directly responsible for the deaths and disability of thousands of workers and citizens worldwide. I guess our politicians and the chrysotile industry value lives in Canada and abroad differently.

It is hypocritical to export chrysotile to other countries. The cynicism that our politicians show in the face of the incontrovertible evidence that our export policies will lead directly to the death of innocent victims is disgraceful. This is a challenge for the Canadian public health community. Will we stand up and fight for populations thousands of kilometres away? Will we expend political capital on a fight that has no direct impact on Canadians? We must. Our credibility is at stake here as much as when we take position on any local public health issue. There is an ethical imperative for Public Health Organizations and professionals, and in particular for Quebec's public health leaders, to become more vocal and active in the fight against chrysotile and to unite behind a common goal of banning production and export of all asbestos.

Gilles Paradis

Scientific Editor

\section{Il faut interdire toute la production et l'exportation de I'amiante chrysotile}

L'image troublante en page couverture de ce numéro de la Revue canadienne de santé publique montre une enfant triant à mains nues les détritus d'un dépotoir jonché d'amiante en Indonésie. Deux adultes portant des sacs - dont l'un au logo de LAB Chrysotile, une mine d'amiante du Québec - cherchent elles aussi des morceaux de ciment-chrysotile, couramment utilisé dans l'industrie du bâtiment de ce pays. De tels morceaux peuvent être manipulés et découpés par des travailleurs pas mieux protégés que les villageois sur cette image, libérant ainsi des fibres d'amiante dangereuses pour les travailleurs et leurs familles.

J'ai commenté récemment la pratique honteuse du Canada qui consiste à exporter du chrysotile dans des pays à faible revenu et à revenu intermédiaire. Des faits nouveaux exigent une réponse vigoureuse de la communauté de la santé publique : un groupe d'investisseurs indiens propose en effet de sauver de la faillite la mine Jeffrey du Québec, l'un des derniers producteurs de chrysotile du Canada. Avec le crédit garanti par le gouvernement québécois, ceci pourrait faire en sorte que l'exportation du chrysotile se poursuive encore pendant 25 ans. Il ne faut pas que cela se produise.

Tant le gouvernement canadien que celui du Québec soutiennent l'industrie de l'amiante depuis des dizaines d'années. Notre photo d'Indonésie montre que l'argument de l'industrie selon lequel le chrysotile peut être utilisé sans danger est un sophisme. Les pays importateurs d'amiante offrent une protection nulle ou insuffisante à leurs travailleurs. De plus, les risques pour la population générale, comme on le voit ici, sont probablement très grands, impossibles à documenter et à prévenir, et ils persisteront sans doute pendant des décennies. Pendant que les gouvernements au Canada dépensent des millions pour retirer l'amiante des bâtiments publics, les exportations de chrysotile canadien sont directement responsables du décès et de l'invalidité de milliers de travailleurs et de citoyens dans le monde. J'ai l'impression que notre classe politique et l'industrie du chrysotile accordent un prix différent à la vie au Canada et à l'étranger.

Il est hypocrite d'exporter du chrysotile vers d'autres pays. Nos politiciens font montre d'un cynisme déshonorant devant les preuves incontournables que nos politiques d'exportation causent directement la mort de victimes innocentes. Il y a là un défi à relever pour les intervenants canadiens en santé publique. Monteronsnous aux barricades pour des populations à des milliers de kilomètres de nous? Dépenserons-nous du capital politique pour une cause qui n'a pas d'incidence directe sur la population canadienne? Il le faut. Notre crédibilité est en jeu, tout comme lorsque nous prenons position sur une question de santé publique locale. Les organismes et les professionnels de la santé publique, et surtout les responsables de la santé publique au Québec, ont un impératif moral à devenir plus revendicateurs et plus actifs dans la lutte contre le chrysotile et à s'unir derrière l'objectif commun d'interdire la production et l'exportation de toute forme d'amiante.

Le rédacteur scientifique,

Gilles Paradis 